\title{
Correction: The dos and don'ts of influencing policy: a systematic review of advice to academics
}

\section{Kathryn Oliver (10) \& Paul Cairney}

Correction to: Palgrave Communications https://doi.org/10.1057/s41599-019-0232-y, published online 19 February 2019.

The original version of the paper included a mistake in the reference list.

The incorrect reference read:

Quarmby and Quarmby S (2018) Evidence-informed policymaking: does knowledge brokering work? LSE Impact Blog

The correct reference should read:

Quarmby S (2018) Evidence-informed policymaking: does knowledge brokering work? LSE Impact Blog: https://blogs.lse.ac.uk/ politicsandpolicy/evidence-informed-policymaking-knowledge-brokers/

This has been corrected in both the online and PDF article file.

Published online: 17 March 2020

\footnotetext{
(c) (i) Open Access This article is licensed under a Creative Commons Attribution 4.0 International License, which permits use, sharing, adaptation, distribution and reproduction in any medium or format, as long as you give appropriate credit to the original author(s) and the source, provide a link to the Creative Commons license, and indicate if changes were made. The images or other third party material in this article are included in the article's Creative Commons license, unless indicated otherwise in a credit line to the material. If material is not included in the article's Creative Commons license and your intended use is not permitted by statutory regulation or exceeds the permitted use, you will need to obtain permission directly from the copyright holder. To view a copy of this license, visit http://creativecommons.org/licenses/by/4.0/.
}

(C) The Author(s) 2020 